\title{
ELECTROPHILIC CYCLIZATION OF DITERPENOIDS ${ }^{\S}$
}

\author{
V. Kulciți, M. Grinco, P. F. Vlad and N. Ungur* \\ Institutul de Chimie al Academiei de Ştiințe a Moldovei, str. Academiei 3, MD-2028, Chişinău, Republic of Moldova \\ *E-mail:n_ungur@yahoo.co.uk; Phone: 37322 739769; Fax: 37322739954
}

\begin{abstract}
A review of diterpenoid cyclization initiated by electrophilic reagents is provided. Conventional protonic and Lewis acids are examined along with superacids as initiators of cyclization cascade. An emphasis is placed on the use of cyclization reactions as a tool for the synthesis of compounds with potential practical utility. The review contains 74 references.
\end{abstract}

Keywords: isoprenoids, diterpenoids, electrophilic cyclization, superacids.

\section{Introduction}

Terpenoids, also referred to as isoprenoids, are a large and diverse group of naturally occurring organic compounds. These lipids-like substances have been isolated from all classes of living species, and are the largest group of natural products. They can be found everywhere: in humans and animals, in terrestrial plants and marine organisms, and even in fossil sediments. Plant terpenoids are extensively used for their flavoring action. They play an essential role in traditional herbal remedies, participate in the growth regulating processes of plants, insects' metamorphosis and are under investigation for a large spectrum of pharmacological activities, including antibacterial and anti-cancer properties. Terpenoids contribute to the scent of roses and eucalyptus, the flavors of cinnamon and peppermint, the odor of lavender and sage. The steroids in animals are also biosynthesized from terpenoid precursors. Sometimes terpenoids are found in living systems connected to compounds of different chemical nature, like proteins, quinones, heterocyclic compounds, playing a major role in the critical metabolitic steps of living beings.

From the chemical structure point of view, terpenoids derive from only a single precursor, the C-5 isoprene unit. But combining this unit in different ways and with different functional groups and stereochemical arrangement provides an infinite number of structures. The cyclic structures, formed in the living systems from open chain terpenic precursors after enzymatic cyclizations, provide additional opportunities for chemical diversity, due not only to the number of carbon atoms, cycles and their size but also to their junction mode, presence of different functional groups and their stereochemistry. That's why cyclic terpenoids have been always a challenging target for synthetic organic chemists. Different biogenetical schemes have been suggested to correlate the structure of cyclic terpenoids with their open chain "parents". The basis of all these schemes was the biogenetic isoprene rule formulated by Ruzicka [1,2]. The methods of organic chemistry provided reliable tools to prove all biogenetical correlations and to provide efficient methods of access to valuable terpenoids in a biomimetic manner. The electrophilic cyclization appears to be one of the more efficient method for both modeling the biochemical processes and target oriented synthesis of natural products that are hardly accessible by other means. These investigations contributed to the elucidation of a number of biogenetic processes mechanisms, confirmed by efficient biomimetical synthesis, which are as a rule the most efficient, short and economical. As external electrophyles both conventional acids and superacids have been broadly used. We will focus our attention only to the cyclization of diterpenoids, which consist of four isoprenic units and have bold representative among compounds with high practical utility. Besides, diterpenoids are widely distributed in Moldovan flora and represent a high potential for efficient exploration.

\section{Cyclizations induced by conventional protonic and Lewis acids}

One of the first papers related to the cyclization of diterpenoids was the work of Ruzicka and Hosking [3]. The cyclization of agathic acid $\mathbf{1}$ was investigated under the action of formic acid (Scheme 1).<smiles>CC(C)=CCC1C(=CC(=O)O)CCC2[C@@](C)(C(=O)O)CCC[C@]12C</smiles>

1

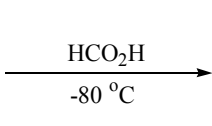

$\mathrm{HO}_{2} \mathrm{C}$

$$
2
$$

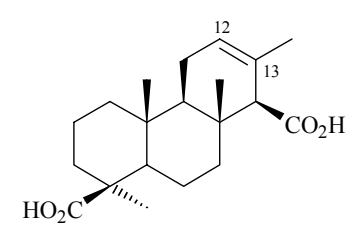

3

§ Dedicated to the memory of Academician Gh.V. Lazurievski (1906-1987), a promoter of natural product chemistry research in the Republic of Moldova. 
It was shown, that $\mathbf{1}$ is converted to isoagathic acid $\mathbf{2}$. The structure $\mathbf{2}$ was assigned in the original paper on the basis of chemical transformations. But the definitive structure of this compound was established by French chemists [4, 5]. Investigating the IR and NMR spectra of dimethyl ester of isoagathic acid, they came to the conclusion that the double bond is trisubstituted and is located between $\mathrm{C}_{12}-\mathrm{C}_{13}$ carbon atoms. Consequently, isoagathic acid is represented by formula 3 (Scheme 1). In such a way the cyclization reaction takes place in a structure- and stereoselective manner, providing the $\alpha$-isomer of the tricyclic product.

The structural and stereochemical outcome of electrophilic cyclization of compounds related to agathic acid was investigated in detail [5-7]. The substrates of choice were the stereoisomeric hydroxi-esters 4 and 5, as well as their dehydration products 6 and 7. The later ones were obtained using as a dehydration agent phosphorus oxychloride in pyridine $[5,7]$ that gave as predominant products olefins with exocyclic double bond (Scheme 2).

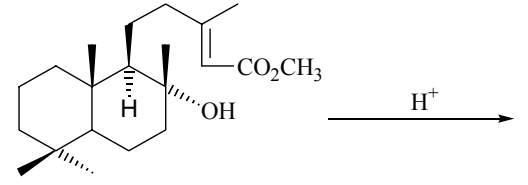

4

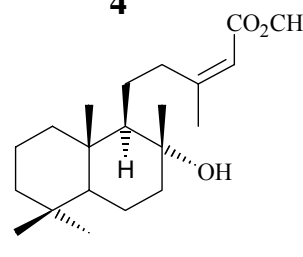

5<smiles>CC(=O)C=C(C)CCC1=C(C)CC[C@H]2C(C)(C)CCC[C@]12C</smiles>

10<smiles>CC(=O)OC1C(C)=CC[C@@H]2C1(C)CC[C@H]1C(C)(C)CCC[C@@]12C</smiles>

8<smiles>CC(=O)O[C@H]1C(C)=CC[C@H]2[C@@]3(C)CCCC(C)(C)C3CC[C@@]21C</smiles>

9<smiles>CC(=O)/C=C(\C)CCC1=C(C)CC[C@H]2CC(C)(C)CCC[C@]12C</smiles>

11

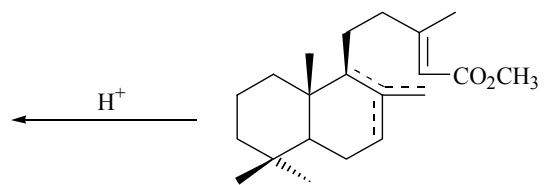

6<smiles>CC(=O)C=C1C=C2CC[C@H]3C(C)(C)CCC[C@]3(C)[C@H]2CC1</smiles>
7<smiles>[R]OC(=O)C=C(C)CC[C@H]1C(=C)CC[C@H]2C(C)(C)CCC[C@]12C</smiles>

$12 \mathrm{R}=\mathrm{H}$

$13 \mathrm{R}=\mathrm{CH}_{3}$

Scheme 2

It was established, that all bicyclic compounds with the same configuration of the lateral chain provide the same tricyclic $\alpha$-isoagathic ester under the action of formic acid. It was concluded that as an initial step in the cyclization process of $\mathbf{4}$ and $\mathbf{5}$ is their dehydration followed by cyclization. This cyclization is initiated by a stereospecific protonation of the $\Delta^{8(9)}$-double bond at $\mathrm{C}_{9}$ from the less hindered $\alpha$-face of the molecule which generates the carbonium ion at $\mathrm{C}_{8}$. It was shown that cyclization of $\Delta^{13}$-trans and $\Delta^{13}$-cis mixtures of esters $\mathbf{6}$ and 7 , as well as of individual isomers with $\Delta^{8(9)}$ - and $\Delta^{8(17)}$ double bonds leads in a stereospecific way to isoagathic esters 8 and 9.

Synthesis of tricyclic isoagathic esters 8 and 9 was reported in a series of following papers [8-12]. Cimino et al. [8] obtained these compounds by cyclization of stereoisomeric esters $\mathbf{1 0}$ and $\mathbf{1 1}$ of labdanic structure with concentrated formic acid (Scheme 2).

Ester $\mathbf{8}$ is the main reaction product of the cyclization of the acid $\mathbf{1 2}$ with concentrated formic acid, followed by methylation with diazomethane. Direct cyclization of the ester 13 provides also the tricyclic ester 8 [4-7]. Consequently, positioning of the double bond in cycle B does not influence the structure and stereochemistry of the formed cyclic products.

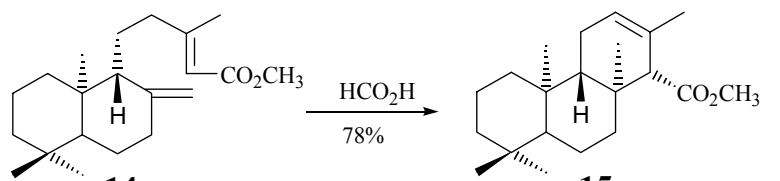

14

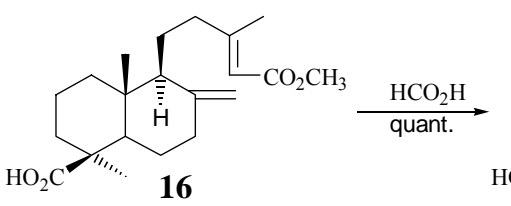<smiles>[GeH2]</smiles>

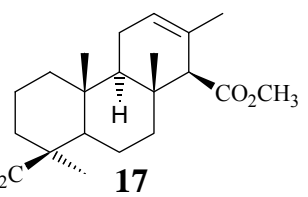<smiles>CC(=O)/C=C1/CC[C@H]2CCCC[C@]2(C)[C@H]1CO</smiles>

18

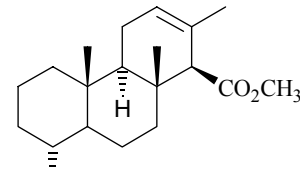

19

Scheme 3 
The cyclization of ent-labdadienoic acid methyl ester $\mathbf{1 4}$ has been also performed (Scheme 3). On interaction of 14 with concentrated formic acid ent-isoagathic ester $\mathbf{1 5}$ was formed in a 78\% yield [13].

The isoagathic acid monomethyl ester $\mathbf{1 7}$ was obtained in a quantitative yield on cyclization of agathic acid monomethyl ester 16 in the same reaction conditions [14]. The absence of one methyl group at $\mathrm{C}_{4}$ in the norlabdanic ester 18 does not influence the cyclization reaction course [15]. In this case the tricyclic 19-norisoagathic ester 19 was obtained in a $90 \%$ yield (Scheme 3 ).

Manool 20 and isomeric labdadienol 21 were reported to cyclize also on treatment with protonic acids [17, 21]. Hydrocarbons 22-25 along with hibanol 28 were isolated, but the oxygenated reaction products were not investigated in detail, though they constituted cca. $50 \%$ of the reaction products mixture. In an attempt to fill this gap, related to labdanic derivatives, the mixture of allylic labdanylacetates 26, readily available from sclareol 27, was submitted to cyclization under the action of a mixture of concentrated sulfuric and formic acids [18, 19]. The reaction product composition was very complex (Scheme 4) and consisted of hydrocarbon fraction, formates and alcohols. In this case only the oxygenated fraction was investigated, since the hydrocarbon fraction was studied in detail in the previous works [16, 17, 20-23].

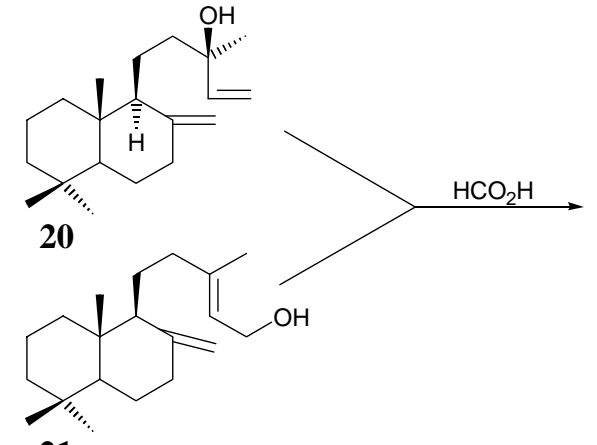

21

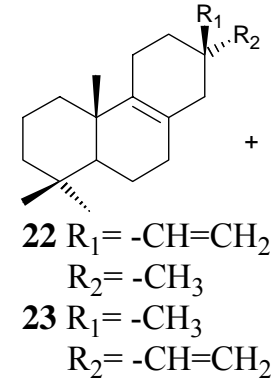

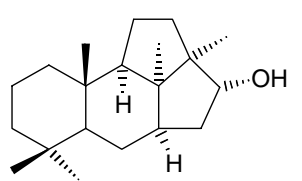

33

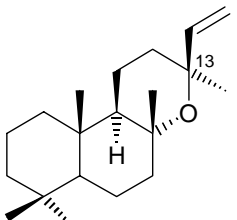

34

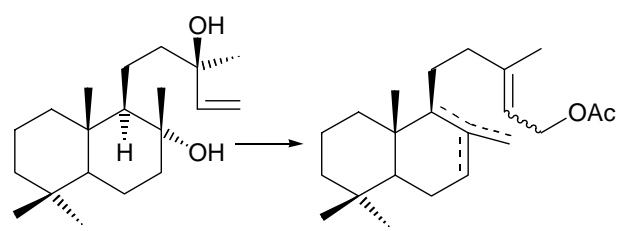

27
26

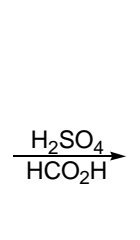

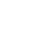

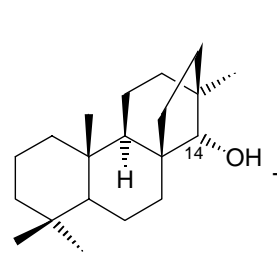

28

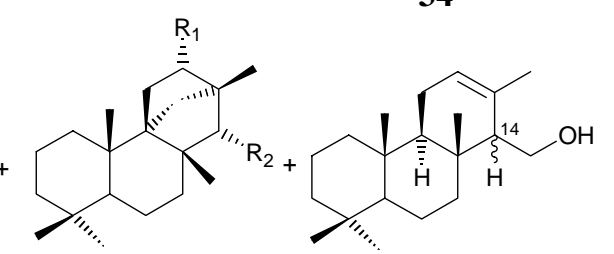

$\begin{aligned} & 29 \mathrm{R}_{1}=\mathrm{H} ; \mathrm{R}_{2}=\mathrm{OH} \\ & 30 \mathrm{R}_{1}=\mathrm{OH} ; \mathrm{R}_{2}=\mathrm{H}\end{aligned} \quad+\begin{array}{r}3114 \alpha \mathrm{H} \\ 3214 \beta \mathrm{H}\end{array}$

Scheme 4

The alcoholic fraction consisted of five components 28-32, which were formed also on hydrolysis of the formiates fraction, but in different relative ratio. The structure of these components was elucidated by chemical transformations and spectral analysis. One of the reaction products, alcohol $\mathbf{3 0}$ was found identical with the alcohol obtained in good yield on the cyclization of sclareol 27 with perchloric acid [24]. Basing on experiments with deuterated substrates [19] the structure 33, originally assigned in [24] was found not correct and the alcohol obtained on sclareol cyclization was represented by formula 30 .

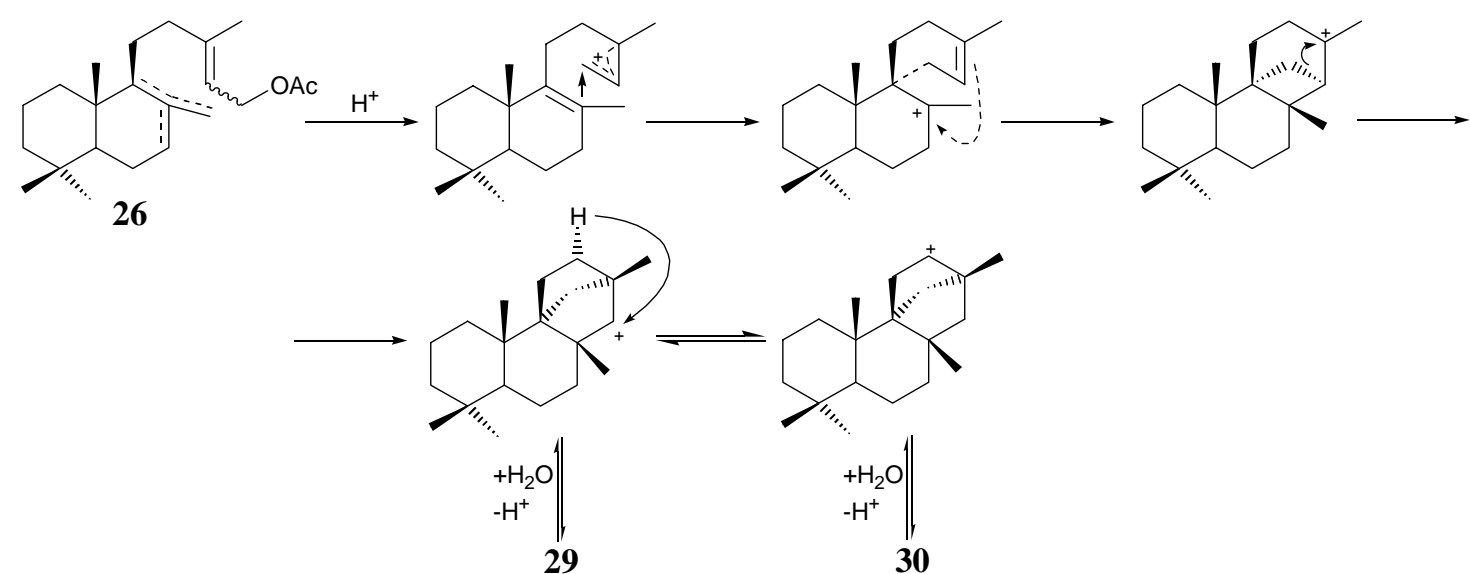

Scheme 5

It was also established, that compounds 28-32 are formed on cyclization of different labdanes (manool 20, sclareol 27, 13-epimanoiloxide 34 and others) with conventional acids or their mixtures [19]. Moreover, some hydrocarbons 
obtained in these reactions were found to be identical with the hydrocarbons obtained on treatment of alcohols $\mathbf{3 1}$ and 32 with the same reagents [25]. It was a proof, that initially formed alcohols are cyclized further in the acidic media to provide the corresponding hydrocarbons.

The reaction mechanism that brings about formation of tetracyclic compounds $\mathbf{2 9}$ and $\mathbf{3 0}$ with the new carbon skeleton is shown in Scheme 5. This mechanism was proved by experiments with deuterated substrates, as well as by the investigation of the cyclization of 13Z-labda-8(9),13-dien-15-ol 35 initiated by titanium chloride-N-methylaniline complex [26]. On performing the cyclization reaction in a wide range of temperature conditions, the predominating isolated product was the chloride 40. It's structure was elucidated on the basis of spectral data, as well as after its preparation from alcohol 30, followed by its reduction to provide the known hydrocarbon $\mathbf{4 1}$ (Scheme 6). The absence of the hypothetical chloride $\mathbf{3 9}$ among the reaction products proves that the initially formed carbonium ion rearranges to the new skeletons and finally leads to alcohols $\mathbf{2 9}$ and $\mathbf{3 0}$ or chloride $\mathbf{4 0 .}$<smiles>C=CC(O)(O)CCC1=C(C)CCC2C(C)(C)CCCC12C</smiles>

36<smiles>CC(=O)OC/C=C(\C)CCC1=C(C)CCC2C(C)(C)CCC[C@]12C</smiles>

35<smiles>CC1=C(CC/C(C)=C/CO)C2(C)CCCC(C)(C)[C@@H]2CC1</smiles>

38

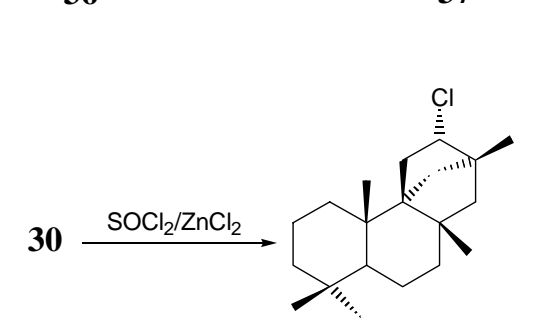

40

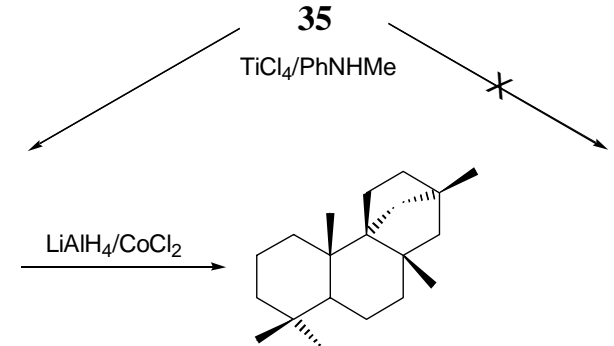

41<smiles>CC1=CC2(Cl)CC[C@H]3C(C)(C)CCC[C@]3(C)[C@]2(C)C1</smiles>

39

Scheme 6

On the other hand, the information on the cyclization of open chain aliphatic diterpenic acids and their esters is rather scarce. Caliezi and Schinz [27] reported cyclization of geranylgeranic acid $\mathbf{4 2}$ under the action of a mixture of sulfuric and formic acids. A fraction of tricyclic compounds was isolated in a $40 \%$ yield, consisting according to authors of $\alpha$ and $\beta$-tricycloizoagathic acids 43 and 44 (Scheme 7).<smiles>CC1=CCCC(C)=CCCCC(C)=C1</smiles>

42<smiles>CCOC(=O)/C(C)=C/CC/C(C)=C/CC/C(C)=C/CCC=C(C)C</smiles>

45<smiles>CCOC(=O)C=C(C)CCC=C(C)CCC=C(C)C</smiles>

46<smiles>CC(=O)C=C(C)CCC=C(C)CCC=C(C)C</smiles>

51<smiles>CC1=CC[C@@H]2[C@](C)(CC[C@H]3C(C)(C)CCC[C@]32C)C1C(=O)O</smiles>

43<smiles>CCOC(=O)C1=C(C)C=CC[C@@H]2C[C@]13CC[C@@H]1C(C)(C)CCCC1(C)CC[C@H]23</smiles>

47

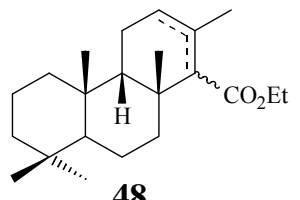

48<smiles>CC(=O)C=C(C)CCC=C(C)CCC1=C(C)CC[C@H](Br)C1(C)C</smiles>

52 (50\%)<smiles>CC1=C(C(=O)O)[C@]2(C)CC[C@H]3C(C)(C)CCC[C@]3(C)[C@H]2CC1</smiles>

44<smiles>C=C(/C=C1\C(=C)CC[C@H]2C(C)(C)CCC[C@]12C)CC/C(C)=C/CC</smiles>

49<smiles>C=C1CCC2C(C)(C#N)CCC[C@]2(C)C1CC/C(C)=C/C(=O)OCC</smiles>

50<smiles>CC(=O)C=C(C)CCC1=C(C)CC[C@H]2C(C)(C)[C@H](Br)CC[C@]12C</smiles>

$53(20 \%)$

Scheme 7 
But the attempts to separate this fraction into individual compounds failed. Besides, the stereochemistry of the initial compound was still unclear, as well as the structure and stereochemistry of the reaction products.

Authors [28] performed the cyclization reaction of the mixture of esters $\mathbf{4 5}$ and $\mathbf{4 6}$ under the action of $100 \%$ sulfuric acid in nitromethane. A complex mixture of tricyclic 47, 48 and bicyclic products 49 and $\mathbf{5 0}$ has been obtained (Scheme 7). It was concluded on the basis of spectral data that the reaction is stereospecific, though structural nonselective. Due to the high complexity of the reaction products composition it was not possible to isolate individual compounds and to prove their structure and stereochemistry univocally.

Japanese chemists [29] investigated the cyclization of the geranylgeranic acid methyl ester $\mathbf{5 1}$ under the action of 2,4,4,6-tetrabromocyclohexa-2,5-diene in acetonitrile to obtain a mixture of mono- and bicyclobromoesters 52 and 53 (corresponding yields 50\% and 20\%). Although the monocyclic derivative 52 predominates (Scheme 7), the structural selectivity of the reaction is low.<smiles>CO[C@@H](CCC=C(C)C)CC/C=C(\C)CCCC(C)=O</smiles>

54<smiles>CCCCOCCO</smiles><smiles>CC(=O)CC1(CCC2=C(C)CC[C@@H]3C(C)(C)CCC[C@@]23C)OCCO1</smiles>

$57(30 \%)$<smiles>CC(=O)CC(=O)CCC1=C(C)CC[C@H]2C(C)(C)[C@H](C)CC[C@]12C</smiles>

55<smiles>CC(=O)[C@H]1CC[C@H]2C(C)(C)CCC[C@]2(C)[C@H]1CC1(C(C)=O)OCCO1</smiles>

$58(30 \%)$<smiles>CC(=O)[C@H]1C(=O)CC[C@@H]2[C@]3(C)CC[C@@H](C)C(C)(C)C3CC[C@@]12C</smiles>

56

Scheme 8

Corey and Burk [30] studied the cyclization of the norditerpenic silylenolether $\mathbf{5 4}$ promoted by mercury trifluoroacetate in nitromethane (Scheme 8). A mixture (1:1) of bi- and tricyclic mercurated ketoesters 55 and $\mathbf{5 6}$ was obtained. This mixture was subjected to ketalization with a subsequent sodium borohydride reduction. As a result, the mixture of compounds 57 and 58 was obtained (yield 30\% for each compound) and separated chromatographically. The stereochemical outcome of the reaction, in particular the configuration at the $\mathrm{C}_{14}$ asymmetric center in $\mathbf{5 6}$ and $\mathbf{5 8}$ is determined by termodinamical control. In this case the cyclization reaction is not structurally selective and the yields of cyclic products are low.

Electrophilic cyclization of labdanic alcohols and esters has been discussed in detail in a former review [31]. Cyclization of similar diterpenic substrates has been reported in the following period. Authors [32] investigated cyclization of geranylgeraniol esters 59 and $\mathbf{6 0}$ with the complex of mercury triflate-N,N-dimethylaniline. The results of this work showed that the cyclization in this case is not a univocal process. On the cyclization of the $p$-nitrobenzoate $\mathbf{5 9}$ in nitromethane with the subsequent reduction of the mercurated products with sodium borohydride a mixture of isomeric bicyclic labdadienols 61 and 62 (28\%) and tricyclic isoagath-12-en-15-ol 25 (22\%) was obtained (Scheme 9).

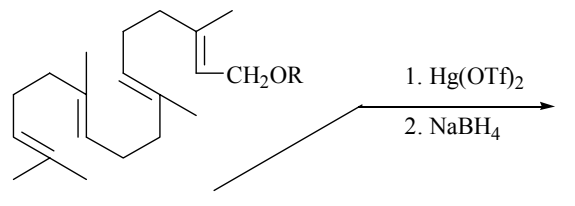

$59 \mathrm{R}=\mathrm{COC}_{6} \mathrm{H}_{4} \mathrm{NO}_{2}$

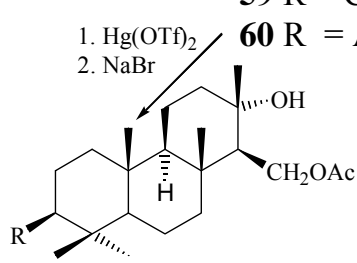

$63 \mathrm{R}=\operatorname{HgBr}(13 \%)$

$69 \mathrm{R}=\mathrm{H}(8.8 \%)$<smiles>CC(=CCO)CCC1=CCCC2C(C)(C)CCC[C@]12C</smiles>

$\left.\begin{array}{l}\mathbf{6 1} \Delta^{7(8)} \\ \mathbf{6 2} \Delta^{8(9)}\end{array}\right\} \quad(28 \%)$

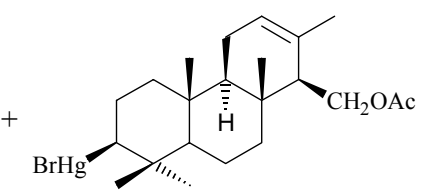

$64(17 \%)$<smiles>CC(=O)OC/C=C(\C)CC/C=C1\CC[C@H]2C(C)(C)CCC[C@@]12O</smiles>

$6510 \alpha \mathrm{OH}(4.9 \%)$

$6610 \beta \mathrm{OH}(0.8 \%)$<smiles>CC1=CC[C@H]2[C@@]3(C)CCCC(C)(C)C3CC[C@]2(C)[C@H]1CO</smiles>

$25(22 \%)$

\section{Scheme 9}

On the other hand, the cyclization of geranylgeranylacetate 60 with the same reagent [33-35] followed by substitution of the triflate residue for bromine brings about formation of the mixture of mercurated isoagathanyl acetates 63 (13\%) and $64(17 \%)$. On performing the reaction with the same mercury complex, but in the presence of 12 equivalents of water in nitromethane with subsequent borohydride reduction of the reaction products, a complex mixture of 
monocyclic $65(4.9 \%)$ and $66(0.8 \%)$, bicyclic $67(9 \%)$ and $68(2.9 \%)$ and tricyclic $69(8.8 \%)$ hydroxiacetates was formed $[33,35]$. A substantial portion $(40 \%)$ of initial geranylgeranylacetate 60 remains unreacted. In such a way the structural selectivity of the reaction is extremely low in this case and as a consequence the reaction products represent a complex mixture of compounds.

According to the first conceptions, the cationic cyclization of polienic compounds was considered a concerted process [36-42]. But other data [43, 44], including above mentioned mercury-induced cyclizations in particular [33, 35], showed that this is a stepwise sequence. This conclusion was quite important for biomimethic-like cyclization of open chain substrates. In this case a complete cyclization cascade leads in a spectacular manner to complex molecules incorporating several asymmetric centers. Performing these reactions with optically active substrates leads to single enantiomeric products. In this line, authors [45] showed that the cyclization of the optically active terminal epoxide of trimethylsilyl derivative of geranylgeranylacetate 70 with Lewis acids provide a mixture of (+)-3-hydroxi-9,10-sin- and (+)-9,10-anti-copalols 71 and 72 (Scheme 10). The reaction is not stereospecific in this case. Formation of 71 and 72 is explained by two boat and chair equilibrium conformations $\mathbf{7 3}$ and $\mathbf{7 4}$ adopted by the substrate on the stage of reaction initiation.

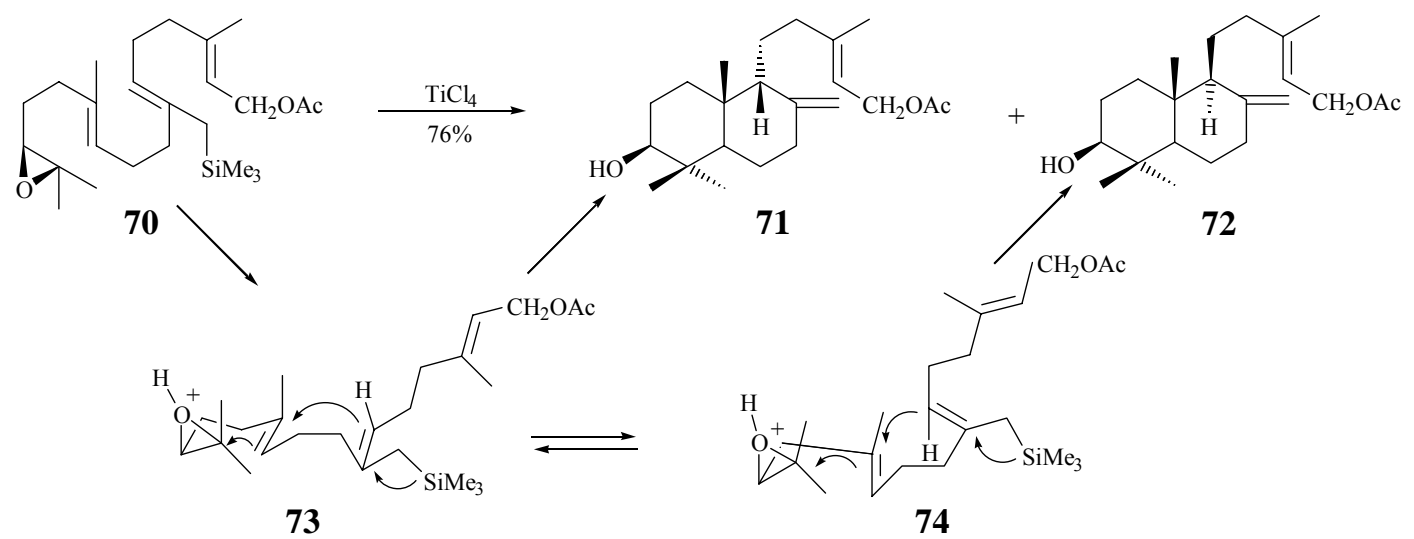

Scheme 10

On the interaction of 13-epimanool 75 with mercury acetate in aqueous nitromethane with the subsequent reduction of the reaction product with sodium borohydride a mixture of strobane oxide 76 is formed [46] (Scheme 11). Quite unexpectedly, in the same reaction conditions manool 20 gave manoyloxide 77. This fact could be explained only assuming that due to conformational effects and steric hindrance the mercury salt attack on vinyl group of 20 is hampered and as a consequence reaction is initiated from the mercury salt attack on the $\mathrm{C}_{8}-\mathrm{C}_{17}$ double bond on the $\mathrm{C}_{17}$ atom.

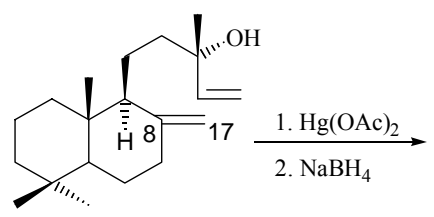

75

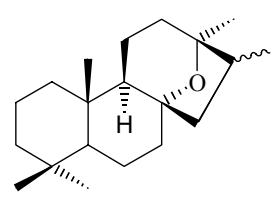

76<smiles>C=C[C@@](C)(O)CC[C@H]1C(=C)CCC2C(C)(C)CCC[C@@]21C</smiles>

20

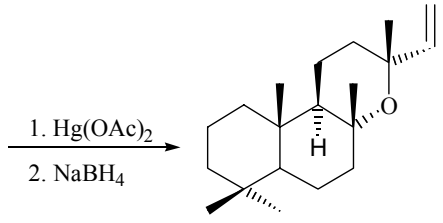

77

Scheme 11

All the above mentioned data show that cyclization of diterpenoids initiated by conventional acids (both protonic and Lewis acids) was not investigated so frequently. Cyclization of bicyclic labdanic compounds with protonic acids has been paid more attention, due to relatively high availability of starting substrates from natural sources. The data on cyclization of open chain diterpenoids are relatively scarce. The available data show that in this case the cyclization reaction does not proceed univocally and structure-selectively, the reaction products are complex mixtures of compounds and its preparative value is not relevant, although it is stereospecific.

\section{Cyclization induced by superacids}

Unlike the usual protonic and Lewis acids, superacids showed more superior cyclization properties in terms of selectivity and mildness of the reaction conditions. The pioneering work of Semenovsky and Smit [47, 48] showed that fluorosulfonic acid can be a very efficient cyclization agent for terpenoids. This reagent proved to be more successful in promoting olefinic cyclization even compared to solvolitic methods of initiation that was broadly used in the synthesis of steroidal compounds [40-42]. 
The first interest towards superacidic cyclization of diterpenoids was due to the necessity of solving the particular question concerning the transformation of labdanes. As it was mentioned in the first part of this review, electrophilic cyclization of labdanic derivatives under the action of usual acids is not selective and provides complex mixtures of bi-, tri- and tetracyclic compounds. But it appeared interesting to get access to natural compounds of izoagathanic structure and it was found that superacids are efficient reagents for transformations of readily available labdanoids into izoagathans. On treatment of a mixture of labdadienol acetates $\mathbf{2 1}$ with fluorosulfonic acid [51] a mixture (3:1) of hydroxiacetates $\mathbf{6 9}$ and $\mathbf{7 8}$ was formed in a respectable 76\% yield (Scheme 12). The unsaturated acetates 79 and 80 were also isolated as minor byproducts (10\%). Cyclization of individual isomers $\mathbf{8 1}$ and $\mathbf{8 2}$ in the same reaction conditions led to the same hydroxiacetates $\mathbf{6 9}$ and $\mathbf{7 8}$ in high yields. The structure of these compounds was elucidated both on the basis of spectral data and several chemical transformations.

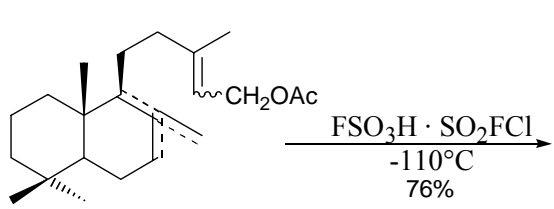

21<smiles>CC(=O)OC[C@@H]1CC[C@H]2[C@]1(C)CC[C@H]1[C@](C)(O)CCC[C@]21C</smiles>

69<smiles>O=S(=O)(O)O[AsH3]</smiles><smiles>CC(=O)OC/C=C(/C)CCC1=C(C)CC[C@H]2C(C)(C)CCC[C@]12C</smiles>

81<smiles>CC(=O)OC[C@H]1[C@@H](O)CC[C@@H]2[C@@]3(C)CCCC(C)(C)C3CC[C@@]12C</smiles>

78<smiles>CC(=O)OC/C=C(/C)CCC1=C(C)CC[C@@H]2C(C)(C)CCC[C@]12C</smiles>

82<smiles>CC(=O)OC[C@H]1C(C)=CC[C@H]2[C@@H]3CCC4C(C)(C)CCC[C@]4(C)[C@H]3CC[C@@H]21</smiles>

$7914 \beta \mathrm{H}$

$8014 \alpha H$

\section{Scheme 12}

Superacidic cyclization of the mixture of ent-copalols $\mathbf{8 3}$ provides also the mixture of isoagathic alcohols 25 and 26 $(85 \%)$ and a minor hydrocarbon fraction $(10 \%)$ where the basic component is the isoagathadiene 84 (Scheme 13).

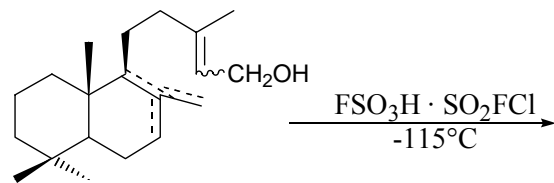

83<smiles>CC1=CC[C@@H]2[C@](C)(CC[C@@H]3C(C)(C)CCC[C@]23C)[C@H]1C[OH2+]</smiles>

25

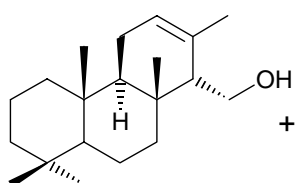

26

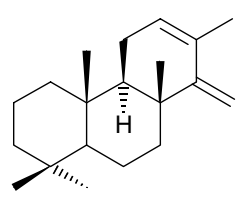

$84(10 \%)$

Scheme 13

Basing on this result, it was established that superacidic cyclization of primary labdanic alcohols and their acetates is a convenient path towards isoagathic diterpenoids. The cyclization reaction is chemoselective and stereospecific. It's course differs essentially from conventional acids induced cyclization of labdanes. On the action of the latter ones the solvolisis of the $\mathrm{C}_{15}-\mathrm{O}$ bond takes place to form the carbonium ion $\mathbf{8 5}$ in the lateral chain, which transforms then into tricyclic pimaranic hydrocarbons and tetracyclic compounds [19]. In the superacidic media, protonation of the double bond in the cycle $\mathrm{B}$ is favored and this leads to $\mathrm{C}_{8}$ carbonium ion $\mathbf{8 6}$ which cyclises to isoagathanes (Scheme 14).

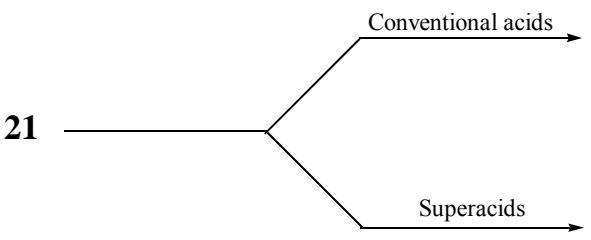<smiles>C=CC(=C)CCC1C(=C)CCC2C(C)(C)CCC[C@]12C</smiles>

85<smiles>CC(=O)OC/C(C)=C/C[C@H]1C(C)CCC2C(C)(C)CCC[C@@]21C</smiles>

86

Scheme 14

Unlike alcohols with primary allylic functional groups $\mathbf{8 3}$ and their acetates 21, superacidic cyclization of labdanes with functional groups at $\mathrm{C}_{13}-$ sclareol 27, manool 20 and isomanool $\mathbf{8 7}$ proceeds by a solvolitic generation of the carbonium ion in the lateral chain. The reaction products are tetracyclic hydrocarbons with new carbon skeletons $\mathbf{8 8}$ and 89 [51, 52] (Scheme 15). 
These results were somehow unexpected and they showed for the first time that the behavior of labdanoids with primary and tertiary allylic oxygen containing functional group in the lateral chain differs in superacidic media. A possible reason for such reactivity could be found in a lower protonation rate of the double bond in cycle B then the solvolysis of the tertiary hydroxyl group in the lateral chain.<smiles>C=C[C@](C)(O)CC[C@@H]1[C@@](C)(O)CC[C@H]2C(C)(C)CCC[C@]21C</smiles>

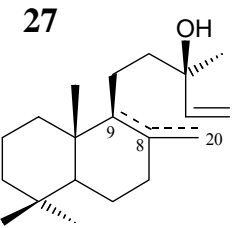

$20 \Delta^{8(20)}$

$87 \Delta^{8(9)}$

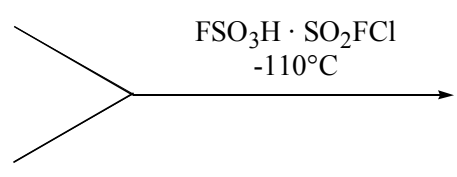

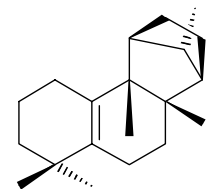

88

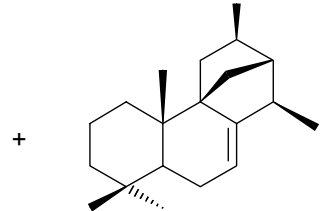

89

\section{Scheme 15}

The first successful results of superacidic cyclization of labdanoids promoted investigation of other diterpenic substrata. Cyclization of open chain diterpenoids was an eloquent example of a biomimetic approach in the synthesis of complex polycyclic diterpenoids. Substrates of choice were E,E,E- and Z,E,E-geranylgeraniols $\mathbf{9 0}$ and 91, as well as their acetates 60 and 92 . On the cyclization of alcohols 90 and 91 with fluorosulfonic acid in 2-nitropropane at $-78^{\circ} \mathrm{C}$ [53, 54] racemic isoagathic alcohols $\mathbf{3 0}$ and $\mathbf{3 1}$ were obtained respectively in high yields (Scheme 16). The main products of the cyclization of acetates 60 and 92 were racemic hydroxiacetates 69 (72\% yield) and 78 (65\% yield). The reaction yields were better in the case of cyclization of $\alpha$-isomers the E,E,E-geranylgeraniol and its acetate 93 and 94 [55]. The terminal isobutenylic group in these substrates is more accessible for protonation [56] and both 93 and 94 provided isoagathanes $\mathbf{3 0}$ and $\mathbf{6 9}$ in $85 \%$ and $78 \%$ yields, that is slightly higher compared to the corresponding $\beta$-isomers $\mathbf{9 0}$ and 60.

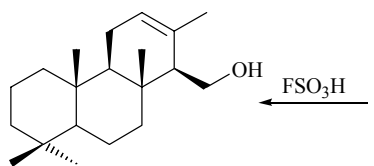

30

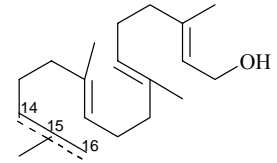

$90 \Delta^{14(15)}(\beta)$

$94 \Delta^{15(16)}(\alpha)$

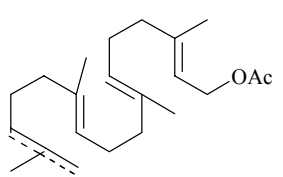

$60 \Delta^{14(15)}(\beta)$

$93 \Delta^{15(16)}(\alpha)$
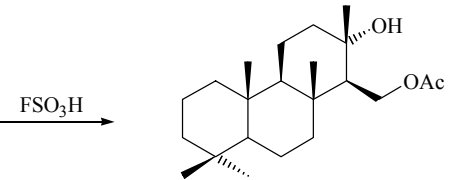

69

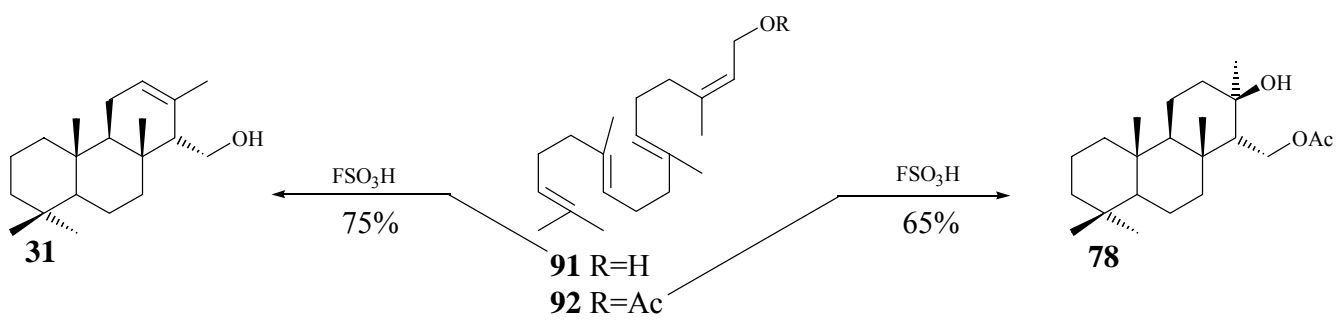

Scheme 16

The range of functional groups compatible with superacidic conditions has been broadened, providing a better flexibility of this cyclization method from the synthetic point of view. As it was mentioned, cyclization of diterpenic acids and their esters has been performed under the action of usual acids. Good results were obtained only in the case of cyclization of bicyclic compounds into tricyclic. The cyclization of open chain diterpenic acids and corresponding esters was not studied at all. On the contrary, superacidic cyclization of these substrata provided very good results [57, 58]. Cyclization of $13 E$ - and $13 Z$-acids 95 and 96 with fluorosulfonic acid $\left(-80^{\circ} \mathrm{C}\right)$, followed by methylation with diazomethane provided the known [4] optically active esters 8 and $\mathbf{9}$ (yields $92 \%$ and $91 \%$ respectively) with isoagathic structure (Scheme 17). These esters were also obtained by direct cyclization of bicyclic esters 10 and 11 (yields $95 \%$ and 91\% respectively). The free acid 97 was prepared on direct cyclization of 95 and used in a following work connected to the synthesis of naturally occurring acylglicerols of marine origine [59]. The following development of this work [60, 61] included an efficient superacidic cyclization of copalic acid 99 (Scheme 18) and the obtained optically active isocopalic acid $\mathbf{1 0 0}$ served as a very convenient template in the synthesis of acylglicerols from the same series. It is noteworthy mentioning, that diterpenoid 1,2-diacyl-sn-glycerols are much more potent activators of protein 
kinase $\mathrm{C}$ than the linear long chain analogs, such as 1,2-dioleoyl-sn-glycerol [62] These enzymes are very relevant regulators of important biochemical events, including gene expression, cell proliferation and down-regulation of receptors [63].

The open chain $E, E, E$ - and Z,E,E-geranylgeranic acids $\mathbf{4 2}$ and $\mathbf{1 0 1}$ were cyclized biomimetically with fluorosulfonic acid and provided after methylation the racemic isoagathic esters $\mathbf{8}$ and $\mathbf{9}$ (yields $85 \%$ and $81 \%$ respectively). Conversion of the open chain esters $\mathbf{5 1}$ and $\mathbf{1 0 2}$ has been also reported to provide the same products $\mathbf{8}$ and $\mathbf{9}$ in excellent yields (92\% and $85 \%$ respectively) $[57,64]$.

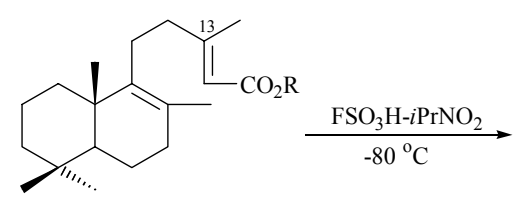

$95 \mathrm{R}=\mathrm{H}$

$10 \mathrm{R}=\mathrm{CH}_{3}$

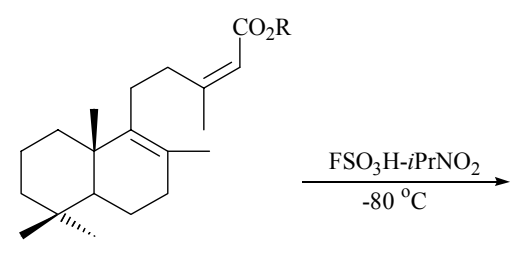

$96 \mathrm{R}=\mathrm{H}$

$11 \mathrm{R}=\mathrm{CH}_{3}$

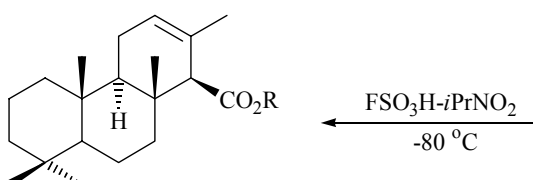

$97 \mathrm{R}=\mathrm{H}$

$8 \mathrm{R}=\mathrm{CH}_{3}$

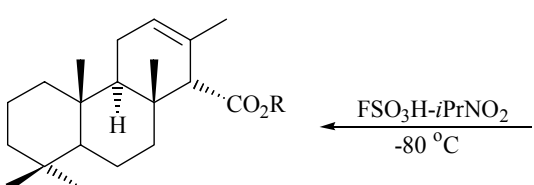

$98 \mathrm{R}=\mathrm{H}$

$9 \mathrm{R}=\mathrm{CH}_{3}$

Scheme 17<smiles>[R]OC(=O)/C=C(/C)CC/C=C(\C)CCC=C(C)C</smiles>

$42 \mathrm{R}=\mathrm{H}$

$51 \mathrm{R}=\mathrm{CH}_{3}$<smiles>[R]C(=O)C=C(C)CCC=C(C)CCC=C(C)C</smiles>

$101 \mathrm{R}=\mathrm{H}$

$102 \mathrm{R}=\mathrm{CH}_{3}$

A very interesting effect was observed on cyclization of bishomo- and bisnorditerpenoids. It was established, that superacidic cyclization of an isomeric mixture of bicyclogeranylacetic acids 103 leeds to a mixture (5:1) of $\delta$-lactones 104 and 105 (Scheme 18) in a 95\% yield [65]. The carboxylic group plays a role of an efficient terminator of cyclization sequence by closing the lactone cycle. For the corresponding ethyl ester 106, the absence of such an efficient terminator leads to a dramatical effect in selectivity: lactones $\mathbf{1 0 4}$ and $\mathbf{1 0 5}$ are formed only in a minor yield (14\%), predominating hydroxyester 107 was isolated in a 35\% yield, along with $32 \%$ of unsaturated tricyclic esters 108 and 109 [66].<smiles>CC(=CCCC(=O)O)CCC1=C(C)C(C)=CC[C@H]2C(C)(C)CCCC12C</smiles>

103

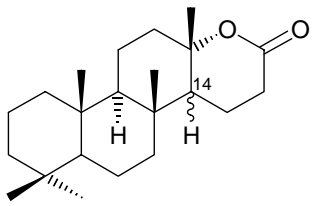

$10414 \alpha \mathrm{H}$ $10514 \beta \mathrm{H}$

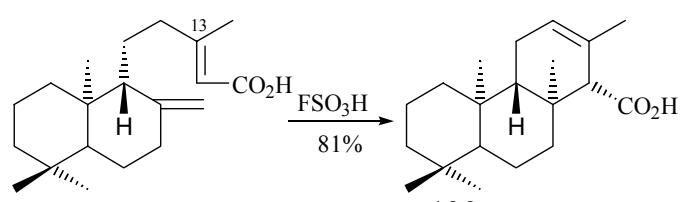

99
100<smiles>CC1=CC[C@@H]2C(C)(C)CCC[C@]2(C)[C@@H]1CC/C(C)=C/CCC(=O)O</smiles>

106

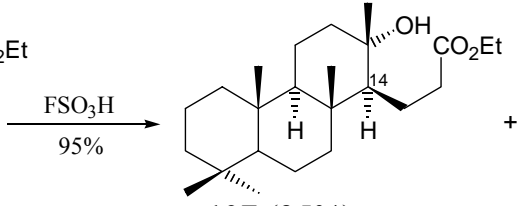

$107(35 \%)$

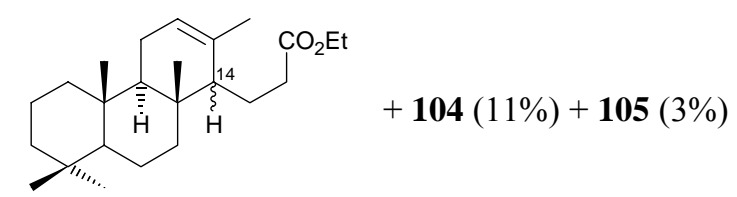

$10814 \alpha \mathrm{H}(23 \%)$

$10914 \beta \mathrm{H}(9 \%)$

Scheme 18

Cyclization of $E, E$ - and $Z, E$-farnesylacetones 110 and 111 was found to provide trans,trans sclareoloxide 112 (67\%) and cis,trans-sclareoloxide $113(65 \%)$ respectively [48]. In this case, the configuration of the internal double bond determines the stereochemistry of ring juncture in the cyclic products (Scheme 19).<smiles>CC(=O)CCC=C1C=C(C)CCCC(C)=C1</smiles>

110<smiles>CC1=CC[C@@H]2[C@@]3(C)CCC[C@H](C)[C@H]3CC[C@@]2(C)O1</smiles>

112 (67\%)<smiles>CC(=O)C/C=C(\C)CC/C=C(\C)CCC=C(C)C</smiles>

111<smiles>CC1=CC[C@H]2[C@@](C)(CC[C@@H]3CCCC(C)(C)[C@]32C)O1</smiles>

$113(65 \%)$

Scheme 19 
These examples show that bishomo- and bisnorditerpenoids cyclization provides a convenient synthetic access to important compounds with biological activity and practical importance [65, 67]. On the other hand, it was revealed that the presence of an oxygenated functional group in the cycle B of bicyclo-bishomoditerpenes 114-117 inhibits initiation of the carbocyclization sequence [66]. The reaction products are a mixture of lactones 118, 119 and hydroxyesters 120122 (Scheme 20).

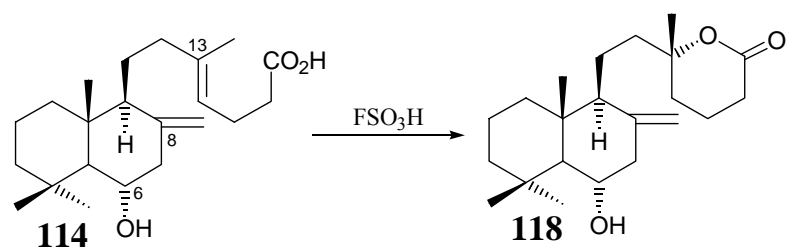<smiles>[R2][C@H]1C[C@H](O)[C@H]2C(C)(C)CCC[C@]2(C)[C@H]1CC/C(C)=C/CCC(=O)O</smiles>

$115 \mathrm{R}=\mathrm{H}$

$116 \mathrm{R}=\mathrm{COCH}_{3}$ $117 \mathrm{R}=\mathrm{COCF}_{3}$

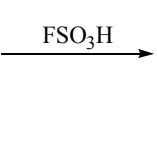<smiles>C=C1C[C@H](O)[C@H]2[C@@H](C)CCC[C@]2(C)[C@H]1CC[C@]1(C)CCCC(=O)O1</smiles>

$118 \mathrm{R}=\mathrm{H}$ $119 \mathrm{R}=\mathrm{COCH}_{3}$<smiles>[R2]O[C@H]1CC(=C)[C@H](CCC(C)(O)CCCC(C)=O)[C@@]2(C)CCCC(C)(C)[C@H]12</smiles>

$120 \mathrm{R}=\mathrm{H}$ $121 \mathrm{R}=\mathrm{COCH}_{3}$ $122 \mathrm{R}=\mathrm{COCF}_{3}$

Scheme 20

Diterpenic phenylsulfones are potential synthons in the synthesis of more complex compounds and their superacidic cyclization has been also investigated [68]. The character of the reaction products was similar to those obtained on cyclization of diterpenic alcohols, acids and esters. Both bicyclic- and open chain substrata provided the same products. $2 E, 6 E, 10 E$-geranylgeranylsulfone 123 and the corresponding bicyclic counterpart 124 cyclized efficiently (Scheme 21) with fluorosulfonic acid under standardized reaction conditions into the tricyclic sulfone 125 (yields $71 \%$ and $85 \%$ respectively). But in the case of $\alpha-Z$ isomeric phenylsulfones a specific effect of the phenylsulfonyl group on the outcome of the cyclization reaction was observed. Both 2Z,6E,10E-geranylgeranylsulfone 126 and the bicyclic sulfone 127 formed on treatment with fluorosulfonic acid under standard conditions the exocyclic isomer 128, along with a minor amount of trisubstituted tricyclic compound 129.

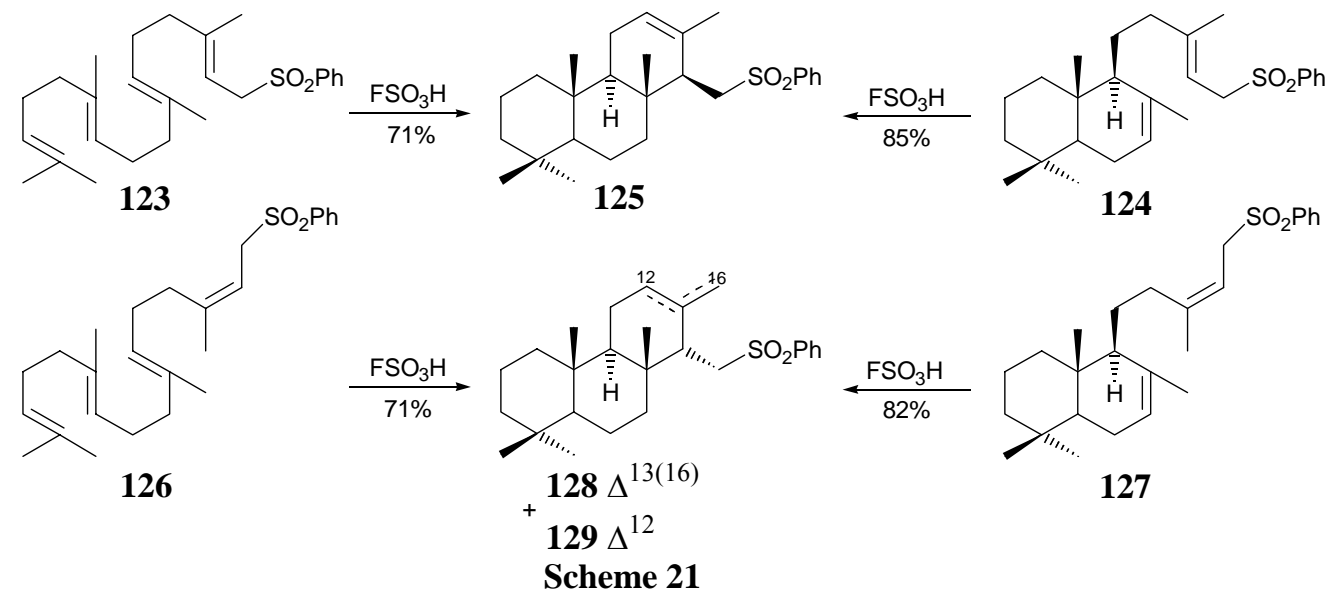

The explanation of this unusual selectivity, caused by the $\alpha$-double bond configuration was given on the basis of a specific interaction of the phenylsulfonyl group with the tricyclic skeleton on the stage of carbonium ion formation. Molecular models simulations showed a specific anchimeric assistance of the phenylsulfonyl residue on the deprotonation process by facilitating the elimination of a proton from a suitable spatially disposed position.

It is noteworthy mentioning that the bicyclic sulfones similar with 124 could be prepared from abundantly occurring sclareol 27 or manool 20. This is a very convenient way to get access to optically active synthons in preparative amounts. 


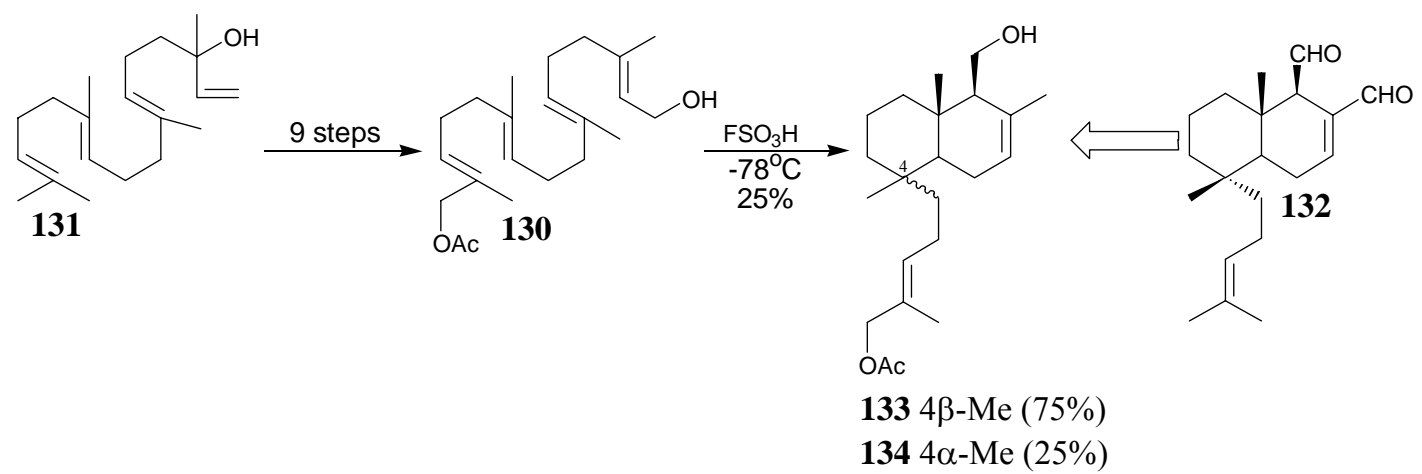

Scheme 22

Superacidic cyclization of more complex diterpenic substrates was reported recently by us and relates to $\alpha, \omega-$ bifunctionalized substrate 130 [69] obtained from geranyllinalool 131. Basing on the data obtained for similar sesquiterpenic $\alpha, \omega$-bifunctionalized substrate [70], we have expected a specific initiation of the cyclization sequence from the internal double bond to give naturally occurring sacculatane skeleton like sacculatadial 132. Under standard cyclization conditions substrate 130 provided the desired sacculatane skeleton 133 along with its $\mathrm{C}_{4}$-epimer $\mathbf{1 3 1}$ in a 25\% overall yield, resolved successfully by HPLC (Scheme 22). The structure of 133 and 134 was elucidated on the basis of spectral data, including 2D-NMR experiments.

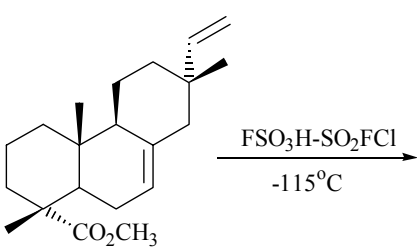

135

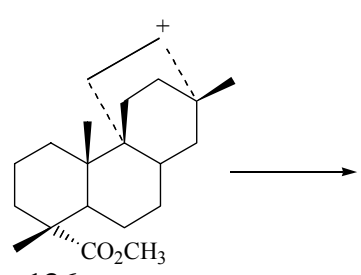

136

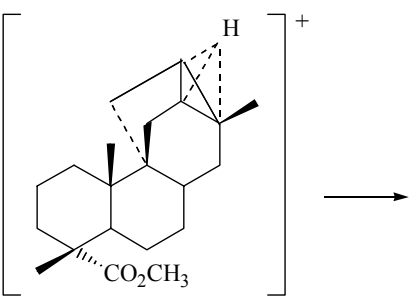

137

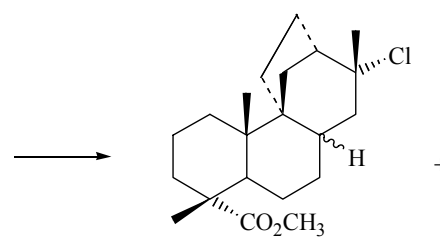

$138(3 \%)$<smiles>CC(=O)[C@]1(C)CCC[C@]2(C)[C@@H]3CC(C)C(C)=C[C@H]3CC[C@@H]12</smiles>

$139(7.8 \%)$

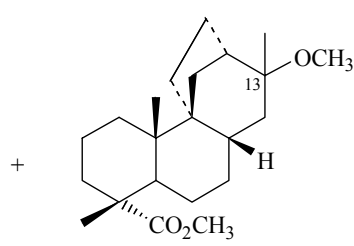

$14013 \alpha \mathrm{CH}_{3}$ $\left.14113 \mathrm{BCH}_{3}\right\} 27 \%$

Scheme 23

More complex cyclization reactions were observed on superacidic treatment of tricyclic diterpenoids. Methylpimarate 135 was treated with fluorosulfonic acid in sulfuryl chloride-fluoride at $-120^{\circ} \mathrm{C}$ [71, 72]. It was established that cyclization reaction takes place via carbonium ions 136 and 137 to form after quenching the neutral tetracyclic diterpenoids of stemodanic structure 138-139 (Scheme 23). Earlier attempts to convert pimaranic compounds into tetracyclic diterpenoids under the action of conventional or Lewis acids failed [31].

All above mentioned results show that fluorosulfonic acid is a highly effective reagent for a biomimetic stereospecific and structurally selective transformation of diterpenic substrates into isoagathic tricyclic compounds. Morover, our results suggested a development of this synthetic tool by combining the superacidic cyclisation with acetylation and following enzymatic hydrolysis to get access to the enantiomerically pure compounds. Our first results in this direction [73] demonstrated that this protocol is synthetically useful. Its optimisation by the known biocatalytic methods [74] seems to be a feasible task.

\section{Conclusions}

All presented data on cyclization of diterpenoids provide an additional confirmation that the electrophilic cyclization, initiated by both conventional and especially superacids represent a general, highly selective and efficient tool for the synthesis of cyclic terpenoids. Superacidic cyclization of open chain and partially cyclized diterpenic alconols, acids and esters, as well as phenylsulfones leads predominantly to $\alpha$-isomers of the corresponding cyclic homoallylic alcohols, acids and esters, where the configuration of the functional group is determined by the stereochemistry of the 
double bond at the $\alpha$-extremity of the initial substrate (Scheme 24). The phenylsulfonyl group shows an anchimeric asistence in the deprotonation process of the cyclic carbonium ion. Superacidic cyclization of primary acetates provides cyclic hydroxiacetates of the diastereomeric 1,3-diols. Their stereochemistry is also determined by the configuration of the initial acetates at $\mathrm{C}_{2}$ (Scheme 24).

Alcohols with primary and tertiary allylic hydroxi-group give different cyclization products under the action of superacids compared to conventional acids.

Cyclization of tricyclic pimaranic compounds leads to products with stemodanic structure.

Superacidic cyclization of bishomo- and bisnorditerpenes is accompanied by a specific interaction of the corresponding functional group and cyclic carbonium ions that brings about formation of lactones and oxides. The oxygenated functional group plays the role of an efficient terminator of the cyclization sequence.<smiles>[R]C=C(C)CCC([CH])=CCC</smiles><smiles>[R]C=C(C)CCC=C(C)C</smiles>

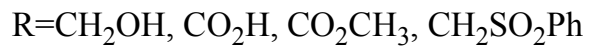<smiles>[Z]C(C)=CCCC(C)=CCOC(C)=O</smiles><smiles>[Y]C(C)=CCCC(C)=CCOC(C)=O</smiles>

\section{Scheme 24}

Cyclization of $\alpha, \omega$-bifunctionalized open chain diterpenoids is initiated predominantly from the internal C10-C11 double bond and provides in a one step sacculatane derivatives - compounds with high biological activity.

\section{References}

[1] Ruzicka, L. Experientia 1953, 9, (10), 357-367.

[2] Ruzicka, L. Proc. Chem. Soc. 1959, (11), 341-360.

[3] Ruzicka, L.; Hosking, J. R. Hohere. Helv. Chim. Acta 1930, 13, 1402-1423.

[4] Asselineau, C.; Bory, S.; Fetizon, M.; Laszlo, P. Bull. Soc. Chim. France 1961, (7), 1429-1431.

[5] Bory, S.; Fetizon, M.; Laszlo, P. Bull. Soc. Chim. France 1963, (10), 2310-2322.

[6] Barton, D.H.D.; Campos-Neves, S.; Cookson, R. C. J. Chem. Soc. 1956, (10), 3500-3506.

[7] Bory, S.; Manh, D. D. K.; Fetizon, M.; Kone, M; Anh, N. T. Bull. Soc. Chim. France 1975, (9-10), 2347-2350.

[8] Cimino, G.; De Rosa, D.; De Stefano, S.; Minale, L. Tetrahedron 1974, 30, (5), 645-649.

[9] Imamura, P. M.; Sierra, M. G.; Ruveda, E. A. J. Chem. Soc., Chem. Commun. 1981, (15), 734-736.

[10] Nakano, T.; Hernandez, M. I. Tetrahedron Lett. 1982, 23, (14), 1423-1426.

[11] Nakano, T.; Hernandez, M. I. J. Chem. Soc. Perkin Trans. I, 1983, (1), 135-139.

[12] Nakano, T.; Hernandez, M. I. J. Chem. Res. 1984, (8), 262-263.

[13] Heissler, D.; Ocampo, R.; Albrecht, P.; Richl, J. J.; Ourisson, G. J. Chem. Soc., Chem. Commun. 1984, (8), 496498.

[14] Fernandez, M. A.; Teresa, J. P.; Gonzalez, R. R. J. Chem. Soc., Perkin Trans. I, 1990, (9), 2429-2435.

[15] Bastard, J.; Do Khas, M. D.; Fetizon, M. Bull. Soc. Chim. France 1989, (11-12), II, 444-448.

[16] Bory, S.; Asselineanu, C. Bull. Soc. Chim. France 1961, (7), 1355-1358.

[17] McCreadie, T.; Overton, K. H. J. Chem. Soc. (C) 1971, (2), 312-316.

[18] Vlad, P. F.; Ungur, N. D.; Koltsa, M. N. Khim. Prirod. Soed. 1979, (4), 581-582. [Chem. Nat. Comp. 1980, 15, (4), 509-510. (Engl. Transl.)].

[19] Vlad, P. F.; Ungur, N. D.; Koltsa, M. N. Tetrahedron 1983, 39, (23), 3947-3958.

[20] McCreadie, T.; Overton, K. H.; Allison, A. J. J. Chem. Soc. (C) 1971, (2), 317-322.

[21] Hall, S. F.; Oehlschlager, A. C. Tetrahedron 1972, 28, (12), 3155-3173.

[22] Wenkert, E.; Kumazawa, Z. Chem. Commun. 1968, (3), 140-142.

[23] Edwards, O. E.; Rosich, R. S. Canad. J. Chem. 1968, 46, (7), 1113-1124.

[24] Joulain, D.; Ruessac, F.; Garnero, J. Tetrahedron Lett. 1977, 18, (40), 3585-3588. 
[25] Ungur, N. D.; Barba, A. N.; Vlad, P. F. Khim. Prirod. Soed. 1988, (5), 719-721. [Chem. Nat. Comp. 1988, 24, (5), 612-614. (Engl. Transl.)].

[26] Vlad, P. F.; Ungur, N. D. Khim. Prirod. Soed. 1984, (3), 318-322. [Chem. Nat. Comp. 1984, 20 , (3), $296-300$. (Engl. Transl.)].

[27] Caliezi, A.; Schinz, H. Helv. Chim. Acta 1952, 35, (5), 1649-1655.

[28] Deadcenko, A. I.; Semenovsky, A. V.; Smitt, V. A.; Kurbanov, M. Izv. Akad. Nauk SSSR, ser. khim. 1977, (6), 1345-1350.

[29] Yamaguchi, Y.; Uyehara, T.; Kato, T. Tetrahedron Lett. 1985, 26, (3), 343-346.

[30] Corey, E. J.; Burk, R. M. Tetrahedron Lett. 1987, 28, (51), 6413-6416.

[31] Vlad, P. F. Izv. Acad. Nauk MSSR, ser. biol. i khim. nauk, 1977, (2), 67.-79.

[32] Nishizawa, M.; Takenaka, H.; Hayashi, Y. Chem. Lett. 1983, (9), 1459-1460.

[33] Nishizawa, M.; Takenaka, H.; Nishide, H.; Hayashi, Y. Tetrahedron Lett. 1983, 24, (25), 2581-2584.

[34] Nishizawa, M.; Takenaka, H.; Hirotsu, K.; Higuchi, T.; Hayashi, Y. J. Am. Chem. Soc. 1984, 106, (15), 42904291.

[35] Nishizawa, M.; Takenaka, H.; Hayashi, Y. J. Am. Chem. Soc. 1985, 107, (2), 522-523.

[36] Jonson, W. S. Acc. Chem. Res. 1968, 1, (1), 1-8.

[37] Stork, G.; Burgstahler, A. W. J. Am. Chem. Soc. 1955, 77, (19), 5068-5077.

[38] Eshenmoser, A.; Ruzicka, L.; Jeger, O.; Arigon, D. Helv. Chim. Acta 1955, 38, (7), 1890-1904.

[39] Johnson, W. S. Angew. Chem. 1976, 88, (2), 33-66.

[40] Johnson, W. S. Bioorg. Chem. 1976, 5, (1), 51-98.

[41] Bartlett, P. A.; Johnson, W. S. J. Amer. Chem. Soc. 1973, 95, (22), 7501-7502.

[42] Johnson, W. S.; Brinkmeyer, P. S.; Kapoor, V. M.; Yarnell, T. M. J. Am. Chem. Soc. 1977, 99, (25), 8341-8343.

[43] Van Tamelen, E. E.; James, D. R. J. Am. Chem. Soc. 1977, 99, (3), 950-952.

[44] Vav Tamelen, E. E. J. Am. Chem. Soc. 1982, 104, (23), 6480-6481.

[45] Yee, N. K. N.; Coates, R. M. J. Org. Chem. 1992, 57, (17), 4598-4608.

[46] Matsuki, Y.; Kodama, M.; Ito, S. Tetrahedron Lett. 1979, 20, (42), 4081-4084.

[47] Kurbanov, M.; Semenovsky, A. V.; Smit, W. A. Izv. Akad. Nauk SSSR, ser. khim. 1973, (2), 390-394.

[48] Muntean, G. E.; Kurbanov, M.; Smit, W. A.; Semenovsky, A. V.; Kucherov, V. F. Izv. Akad. Nauk SSSR, ser. khim. 1973, (3), 633-639.

[49] Johnson, W. S.; Semmelhack, M. F.; Sultanbawa, M. U.; Dolak, L. A. J. Am. Chem. Soc. 1968, 90, (11), 29942996.

[50] Johnson, W. S.; Li, T., Harbert, C. A.; Bartlett, W. R.; Herrin, T. R.; Staskun, B.; Rich, D. H. J. Am. Chem. Soc. 1970, 92, (14), 4461-4463.

[51] Vlad, P. F.; Ungur, N. D.; Barba, A. N.; Tatarova, L. E.; Gatilov, Yu . B.; Korchagina, D. V.; Bagreanskaia, I. Yu.; Gatilova, V. P.; Shmidt, E. N.; Barkhash, V. A. Zh. Org. Khim. 1986, 22, (12), 2519-2533. [J. Org. Chem. U.S.S.R., 1987, 22. (12), 2261-2273. (Engl. Transl.)].

[52] Vlad, P. F.; Ungur, N. D.; Barba, A. N.; Korchagina, D. V.; Bagreanskaia, I. Yu.; Gatilov, Yu .B.; Gatilova, V. P.; Barkhash, V. A. Khim. Prirod. Soed. 1988, (2), 198-203. [Chem. Nat. Comp. 1988, 24 (2), 166-170. (Engl. Transl.)].

[53] Vlad, P. F.; Ungur, N. D.; Nguen, V. H.; Perutskii, V. B. Izv. Akad. RAN, Ser. Khim.. 1995, (12), $2494-2506$. [Russ. Chem. Bull., 1995, 44, (12), 2390-2403. (Engl. Transl.)].

[54] Vlad, P. F.; Ungur, N. D.; Perutskii, V. B. Khim. Prirod. Soed. 1986, (4), 514-515. [Chem. Nat. Comp., 1987, 22, (4), 485-486. (Engl. Transl.)].

[55] Ungur, N. D.; Popa, N. P.; Nguen, V. T.; Vlad, P. F. Khim. Prirod. Soed. 1993, (4), 542-546. [Chem. Nat. Comp., 1994, 29, (4), 473-478. (Engl. Transl.)].

[56] Semenovsky, A. V. Doctoral Thesis, IOH, AN SSSR, Moscow, 1972, 31.

[57] Vlad, P. F.; Ungur, N. D.; Nguen, V. T. Izv. Akad. RAN, ser. khim. 1995, (12), 2507-2513. [Russ. Chem. Bull., 1995, 44, (12), 2404-2411. (Engl. Transl.)].

[58] Ungur, N. D.; Nguen, V. T.; Vlad, P. F. Khim. Prirod. Soed. 1991, (5), 726-728. [Chem. Nat. Comp. 1992, 27, (5), 642-643. (Engl. Transl.)].

[59] Ungur, N.; Gavagnin, M.; Cimino, G. Tetrahedron Lett. 1996, 37, (20), 3549-3552.

[60] Fontana, A.; Ungur, N.; Gavagnin, M.; Salierno, C.; Cimino, G. Tetrahedron Lett. 1997, 38, (23), $4145-4148$.

[61] Ungur, N.; Gavagnin, M.; Fontana, A.; Cimino, G. Tetrahedron 2000, 56, (16), 2503-2512.

[62] De Petrocellis, L.; Orlando, P.; Gavagnin, M.; Ventriglia, M. C.; Cimino, G.; Di Marzo, V. Experientia 1996, 52 , (9), 874-877.

[63] Vance, D. E. Phospholipid metabolism and cell signalling in eucaryotes, in Biochemistry of Lipids, Lipoproteins and Membranes; Neuberger, A.; Van Deenen, L.L.M. Eds; Elsevier: Amsterdam, 1991, 229-230.

[64] Ungur, N. D.; Nguen, V. T.; Vlad, P. F. Khim. Prirod. Soed. 1991, (5), 728-729. [Chem. Nat. Comp., 1992, 27, (5), 643-644. (Engl. Transl.)].

[65] Vlad, P. F.; Ungur, N. D.; Nguen, V. H. Khim. Prirod. Soed. 1990, (3), 346-353. [Chem. Nat. Comp., 1991, 26, (3), 285-291. (Engl. Transl.)].

[66] Ungur, N. D.; Nguen, V. T.; Popa, N. P.;Vlad, P. F. Khim. Prirod. Soed. 1992, (6), 645-654. [Chem. Nat. Comp., 1993. 28, (6), 561-568. (Engl. Transl.)]. 
[67] Ungur, N. D.; Nguen, V. H.; Vlad, P. F. Khim. Prirod. Soed. 1990, (3), 353-358. [Chem. Nat. Comp., 1991, 26, (3), 292-296. (Engl. Transl.)].

[68] Kulcițki, V.; Ungur, N.; Vlad, P. F. Tetrahedron 1998. 54, (39), 11925-11934.

[69] Grinco, M.; Kulcițki, V.; Ungur, N.; Vlad, P.F.; Gavagnin, M.; Castelluccio, F.; Cimino, G.. Ukraine Conference on Organic Chemistry. Odessa. Abstracts of communication. 2004, 1, 153.

[70] Kulcițki, V.; Ungur, N.; Vlad, P.; Gavagnin, M.; Castelluccio, F.; Cimino, G. Synthesis, 2000, (3), 407-410.

[71] Shmidt, E. N.; Gatilov, Yu. B.; Osadchii, S. A.; Korchagina, D. V.; Bardina, N. M.; Polivinca, M. P.; Shevtsov, S. A.; Barkhash, V. A. Zh. Org. Khim. 1981, 17, 1553.

[72] Shmidt, E.N.; Gatilov, Yu .B.; Bagreanskaia, I. Yu.; Korchagina, D. V.; Bardina, N. M.; Polivinca, M. P.; Osadchii, S. A.; Shevtsov, S. A.; Barkhash, V.A. Zh. Org. Khim. 1985, 21, 793.

[73] Serebryakov, E. P.; Gamalevich, G. D.; Kulcitki, V. N.; Ungur, N. D.; Vlad, P. F. Mendeleev Commun. 2002, 12 (2), 59-61.

[74] Drauz, K.; Waldmann, H. Eds. Enzyme Catalysis in Organic Synthesis. VCH, Weinheim, 1995, 1, $178-261$. 